\title{
Архиерейский двор в Тверском кремле: опыт реконструкции
}

\author{
А.М.Салимов, НИИТИАГ, Тверь
}

Епископская кафедра в Твери появилась во второй половине XIII века в период формирования Тверского княжества. Она стала результатом энергичных и весьма дальновидных действий первого тверского князя Ярослава Ярославича, который в середине 60-x - начале 70-х годов XIII века являлся одновременно великим владимирским князем. Тогда же в Тверском кремле началось создание Владычной резиденции, все постройки которой изначально, вероятно, были деревянными. Каменные сооружения появились на архиерейском дворе, по всей видимости, в XV веке - практически одновременно или несколько позже каменных палат Княжьего двора. B XVI веке на территории владычного комплекса строятся новые каменные здания, фасады которых декорируют поливными изразцами по типу тех, что украшали Борисоглебский собор 1558-1561 годов в Старице.

Наивысшего расцвета ансамбль архиерейского двора достигает во второй половине - конце XVII века, когда подавляющее большинство построек комплекса возводят в камне. Без особых изменений Владычная резиденция существовала до пожара 1736 года, который коренным образом изменил судьбу позднесредневекового ансамбля. В результате часть каменных палат была разобрана, а новый архиерейский дворец возвели на ранее свободном от застройки месте. Позже его отдельные компартименты вошли в состав ныне существующего Императорского путевого дворца Екатерины II.

Непростая архитектурная история архиерейского двора в Тверском кремле вот уже почти три десятилетия изучается археологами. За эти годы был накоплен значительный материал, который вкупе с другими источниками позволяет в целом определиться с границами и характером застройки городской резиденции тверского архиерея, где среди зданий комплекса находились каменные постройки XV, XVI и XVII веков ${ }^{1}$.

Ключевые слова: Тверской кремль, Владычный двор, архиерейский дворец, Императорский дворец, Иоасаф.

\section{Archiereus Yard: An Attempt of Reconstruction}

\section{A.M.Salimov, NIITIAG, Tver}

The archiereus cathedra in Tver appeared in the 2 nd half of the 13th century in the period of the Tver Grand Principality

1 Работа выполнена по Программе фундаментальных научных исследований Российской академии архитектуры и строительных наук (РАACH) и Научно-исследовательского института теории и истории архитектуры и градостроительства (филиала ФГБУ «ЦНИИП Минстроя России» НИИТИАГ), а также при поддержке РФФИ, в рамках научного проекта № 19-012-00025. foundation. Its' creation was a result of strong and very farsighted actions of the first Tver prince Yaroslav Yaroslavitch who was at the same time the Grand Prince of Vladimir in the middle 1260es - early 1270 -es. At that time, the creation of the Archiereus residence was started in Tver kremlin. All constructions were probably originally wooden. Stone buildings appeared in the Archiereus Yard evidently in the 15th century practically simultaneously or a bit later of the stone constructions of the Prince's Yard. New stone buildings facades of which were decorated with tiles similar to those that ornamented the St. Boris and Gleb cathedral of 1558-1561 in Staritza were built in the 16th century in the territory of the archiereus complex.

The ensemble of the Archiereus Yard reached its' fullest flower in the 2 nd half - the late 17 th century when most of the complex's constructions were erected of stone. The Archiereus Yard existed without large changes until the fire of 1736 which cardinally modified the late medieval ensemble's destiny. The result was that a part of the stone buildings was demolished while a new archiereus palace was erected at the place free of constructions. Later on, some of its parts were included in the building of the now existing Emperor's Travelling Palace of Catherine the 2 nd.

The complicated architectural history of the Archiereus Yard in Tver Kremlin has been studied by archaeologists for almost three decades. The significant material collected during these years together with other sources allows defining in a whole the borders as well as the character of the building of the city residence of Tver archiereus, where among the constructions of the complex were the stone buildings of the 15th -17 th centuries.

Keywords: Tver Kremlin, Archiereus Yard, Emperor's palace, Ioasaf.

Во второй половине XIII века на стадии формирования Тверского княжества в его столице появилась епископская кафедра. Её создание стало, вероятно, результатом энергичных и весьма дальновидных действий первого тверского князя Ярослава Ярославича, который в середине 60-х - начале 70-х годов XIII века являлся одновременно великим владимирским князем. В этот период, по-видимому, и появился в Твери епископ Симеон, первое упоминание о котором относится к 1271 году2 . Надо полагать, владычная резиденция изначально находилась в Тверском кремле,

2 ПСРЛ. СПб., 1913. Т. 18. С. 74. 
хотя её точное местонахождение вплоть до XVII века не фиксируется источниками. Лишь документы XVII столетия позволяют со всей определённостью разместить Архиерейский двор в северо-восточной части кремля, иллюстрацией чего является рисованный план Твери начала XVIII века (рис. 1)3 ${ }^{3}$ В свою очередь документы конца XVII - начала XVIII века дают возможность порой в деталях представить застройку владычной резиденции.

Уже будучи ансамблем, состоящим в основном из каменных построек, владычный комплекс дважды - в 1736 и 1763 годы - страдал от больших пожаров, что в итоге привело к постройке здесь в 60-X - 70-х годы XVIII века того здания, которое сегодня украшает центр бывшего Тверского кремля (рис. 2). В процессе реставрационных работ, которые начались в начале 1990-х годов, шло археологическое изучение памятника, позволившее определиться с местоположением, границами и характером застройки владычной резиденции.

Наиболее массово средневековые конструкции были обнаружены в 1993-1994 годы у западного крыла дворца и в районе северной стены его центрального корпуса (рис. 3). Здесь удалось выявить остатки трёх-четырёх сооружений, находившихся на этом месте до постройки ныне существующего здания (рис. 4).

Наибольший интерес представляют сооружения, остатки которых были раскрыты в шурфах у западного корпуса. Более ранней постройкой является та, что находится южнее

${ }^{3}$ РГВИА. Ф. 349. 0п. 39. Д. 724.

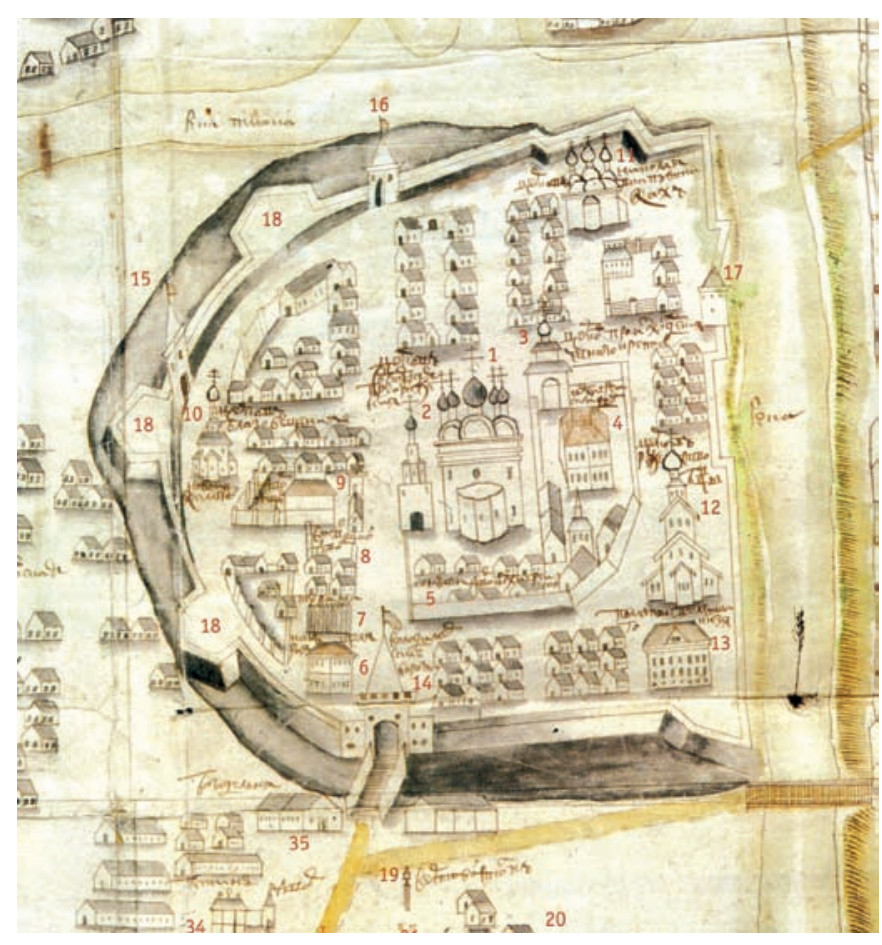

Рис. 1. Тверской кремль на рисованном плане первой четверти XVIII века (источник: РГВИА. Ф. 349. On. 39. Д. 724)
(№ 10 на реконструкции, см. рис. 4), вторая (№ 11) примыкает к ней с севера (см. рис. 4). Их отличает достаточно мощный (180-190 см) фундамент, сложенный в основном из белокаменных блоков с отдельными включениями валунов и фрагментов кирпича. Ориентируясь на опись 1701 года, можно говорить, что в первой из них находился Казённый приказ, казначейская келья, казённая кладовая палата и ещё одна палата. Второе здание (северное) включало квасоварню, поварню и две каменные кельи, которые располагались во втором ярусе над поварней. Важно отметить, что в районе этих зданий были найдены изразцы, некоторые из которых известны в Твери со второй половины XV века (рис. 5), и вообще этот тип архитектурной керамики не выходит за пределы начала - первой трети XVI века. Другие изразцы близки тем, что использовались в

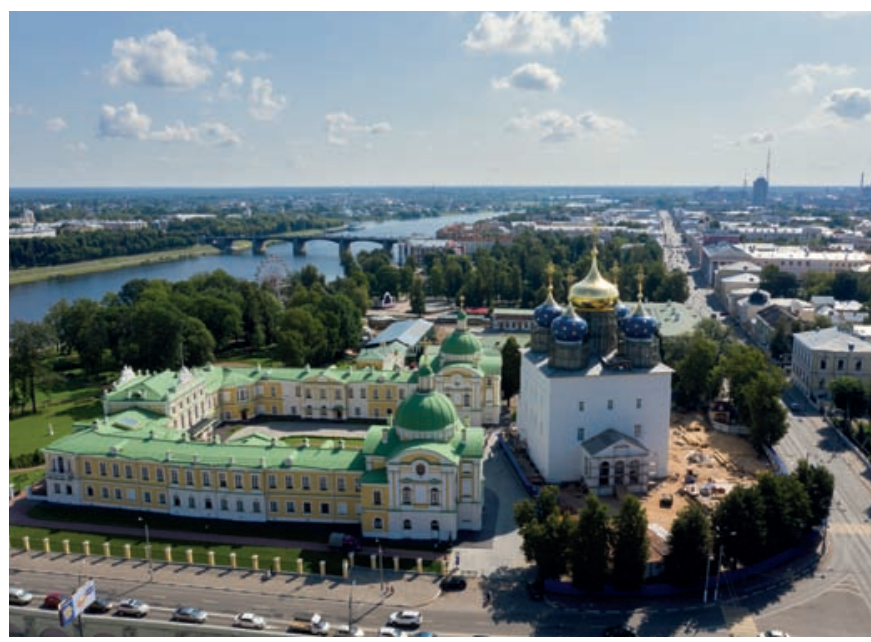

Puc. 2. Расположенные на месте Владычного двора Императорский двореи и кафедральный Спасо-Преображенский собор. Тверь. Фото А. Лясникова. Июль 2019 года

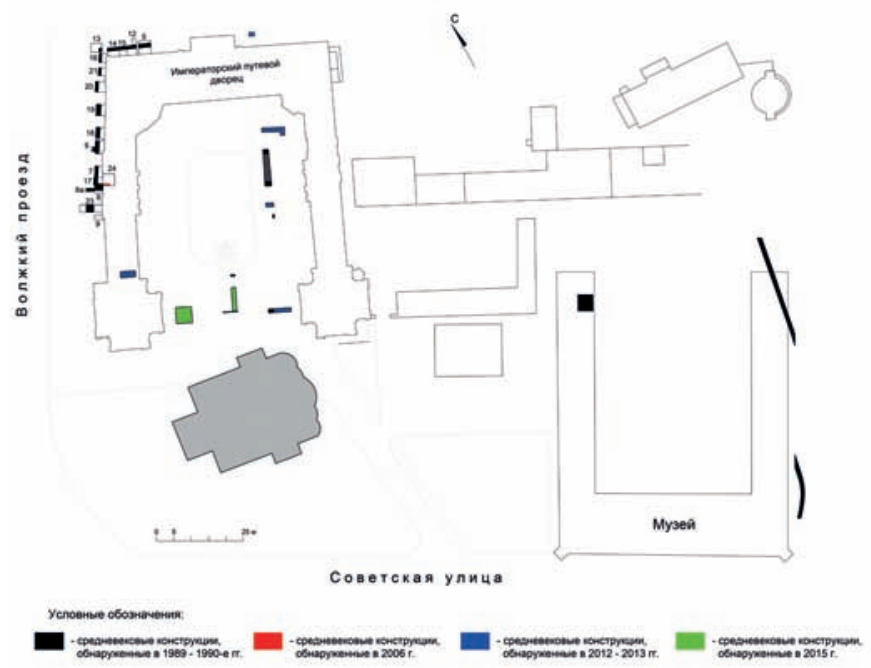

Рис. 3. Сводный план средневековых конструкций, обнаруженных на территории бывшего архиерейского комплекса в 1989-2015 годы. Автор - А.М. Салимов 
1558-1561 годы при декорировке Борисоглебского собора в Старице (рис. 6).

Следует также отметить, что в верхней части выполненного практически полностью из белокаменных блоков фундамента Казённого приказа были зафиксированы фрагменты малоформатного кирпича, известного по московским постройкам XVI века [2, с. 208].

Таким образом, результаты архитектурно-археологических исследований в районе западного крыла Императорского дворца свидетельствуют о том, что каменные постройки на этом месте могли появиться ещё во второй половине XV - начале XVI века. Впоследствии они, вероятно, неоднократно обновлялись, что подтверждается находками изразцов XVI - XVII веков. Но кардинальная реконструкция владычного комплекса в Тверском кремле состоялась, по всей видимости, в 60-е - 70-е годы XVII века, когда после пожара 1661 года архиепископ Иоасаф вёл во владычной резиденции широкомасштабное каменное строительство [3, с. 87-90, 261-262].

В этот период была создана и каменная ограда Архиерейского двора, фрагменты которой были выявлены в различных местах комплекса, а в его восточной части удалось расчистить свайную ленту, уплотнившую дно рва перед закладкой фундамента.

Участок ещё одной каменной постройки (приказ Судных и Духовных дел - № 13) был обнаружен на стыке с южным пряслом ограды, а к западу от неё удалось выявить остатки святых ворот (см. рис. 4).

Вероятно, короткий отрезок ограды связывал святые ворота с церковью Происхождения честных древ Креста

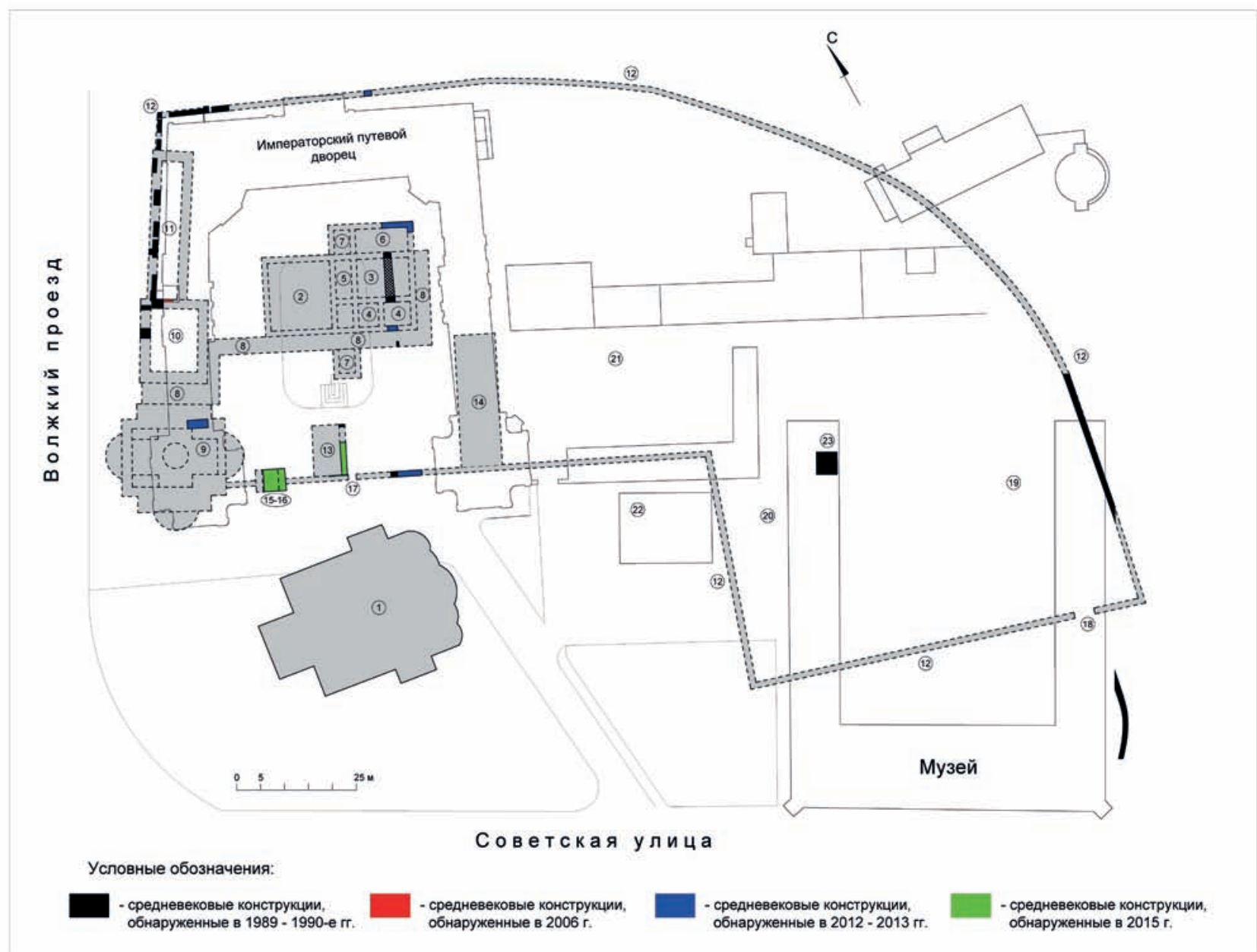

Puc. 4. Тверской Владычный двор нарубежеXVII-XVIII веков. План комплекса. Схематическая реконструкция [наименования построек даны по описям 1685-1686 и 1701-1702 годов (РГАДА. Ф. 1209. Оп. 1.Д. 470; РГАДА. Ф. 237. Оп. 1. Кн. 46)]: 1 -Спасо-Преображенский собор; 2 -столовая палата; 3 - крестовая палата; 4-две кельи архиерейские; 5-сени; 6-келья деревянная о трёхжильях; 7 - из сеней на архиерейской двор переднее и заднее крыльцы и всходы рундуки каменные; 8-переходы каменные; 9 - церковь Происхождения честных древ Креста Господня; 10 - казённой приказ да казначейская келья да казённая кладовая палата да палата каменные на жилых подклетах; 11 - квасоварня да поварня на поварне две кельи каменные; 12 -ограда каменная; 13 - палата Приказ Судных Духовных дел на жилом подклете; 14 - три погреба каменные да полатка на них сушила; 15-въезжие ворота; 16 - святые ворота; 17ворота чтоходят со архиерейского двора в соборную церковь ксеверным дверям; 18-ворота конюшенного двора; 19 - конюшенный двор; 20-житенный двор; 21 -огород; 22 -пустой Афонасьевский монастырь; 23-башнеобразное сооружение. Автор-А.М. Салимов 
Господня. Перепись 1701 года сообщает её размеры $(15 \times 9,6$ м) ${ }^{4}$, но, по всей видимости, они относились ко второму ярусу сооружения, поскольку известно, что домовой храм архиепископа располагался на «сенях», а «сени» являлись теми самыми «старинными подклетами ${ }^{5}$, на которых в 60 -е - начале 70-х годов XVII века был поставлен новый храм. Зафиксированные источником начала XVIII века церковные габариты относились, вероятно, к внутреннему пространству храма, а не кего внешним параметрам. Этот вывод базируется на содержащихся в документе 1701 года обмерах кафедрального собора, который, очевидно, был промерен именно так. В итоге нижний ярус домовой церкви представляется довольно значительным по площади: ориентировочно $22 \times 22$ м.

При реконструкции этого здания предпочтение было отдано квадрифолийному плану, поскольку на чертеже 1674 года постройка изображена триконховой (рис. 7) [4, л. 14]. Возможно, что «сени» архиерейской церкви принадлежали постройке XV-XVI веков, имевшей изначально трёх-, четырёхили восьмилепестковый основной объём [5, с. 380-394].

На начальном этапе изучения владычного комплекса наибольшую сложность в деле локализации построек Архиерейского двора представляла собственно Владычная палата, однако в результате проведённых в 1999 и 2012 годах архитектурно-археологических исследований ${ }^{6}$, остатки последней были выявлены на территории курдонера Императорского дворца (см. рис. 3) [6, с. 119-120].

${ }^{4}$ «... длина той церкви пять сажень, ширина полпяты сажени, олтарю длина две сажени, ширина три сажени, вышина церкви полшесты сажени, олтарю вышина полчетверты сажени» (источник: РГАДА. Ф. 237. 0п. 1. Кн. 46. 1701-1702 гг. Л. 91).

${ }^{5}$ РГАДА. Ф. 1209. 0п. 1. Д. 470. 1685-1686 гг. Л. 38 об.

${ }^{6}$ Салимов А.М. Отчёт об охранных архитектурно-археологических исследованиях Императорского путевого дворца в г. Твери в 2012. - Тверь, 2013.
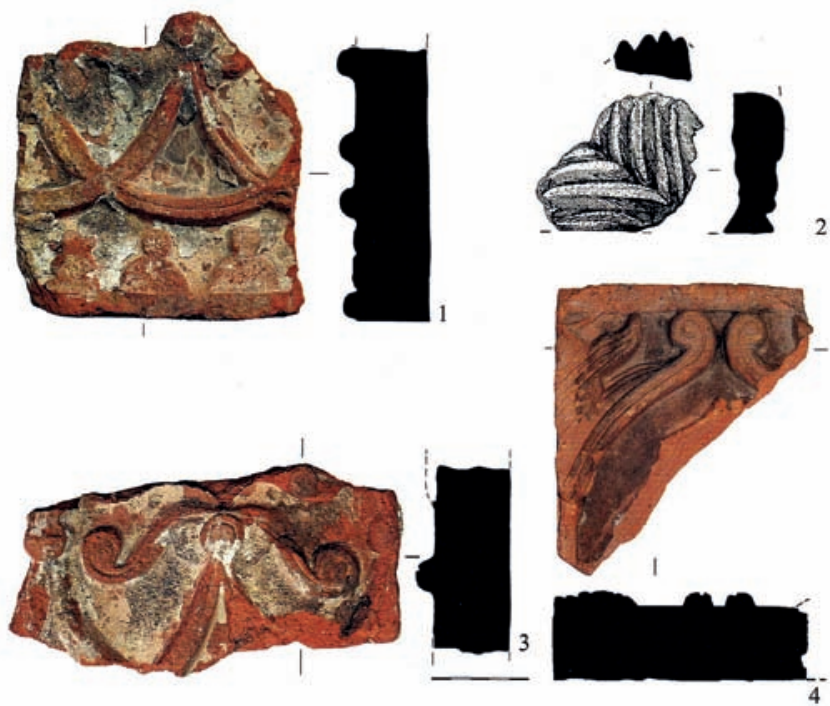

Рис. 5. Фрагменты терракотовых изразцов, обнаруженные в 2012-2013 годы в центральной части западного крыла тверского Императорского дворца. Вторая половина XV-начало XVI века (источник: [1, цв. вклейка: рис. 5, №№ 1, 3, 4])
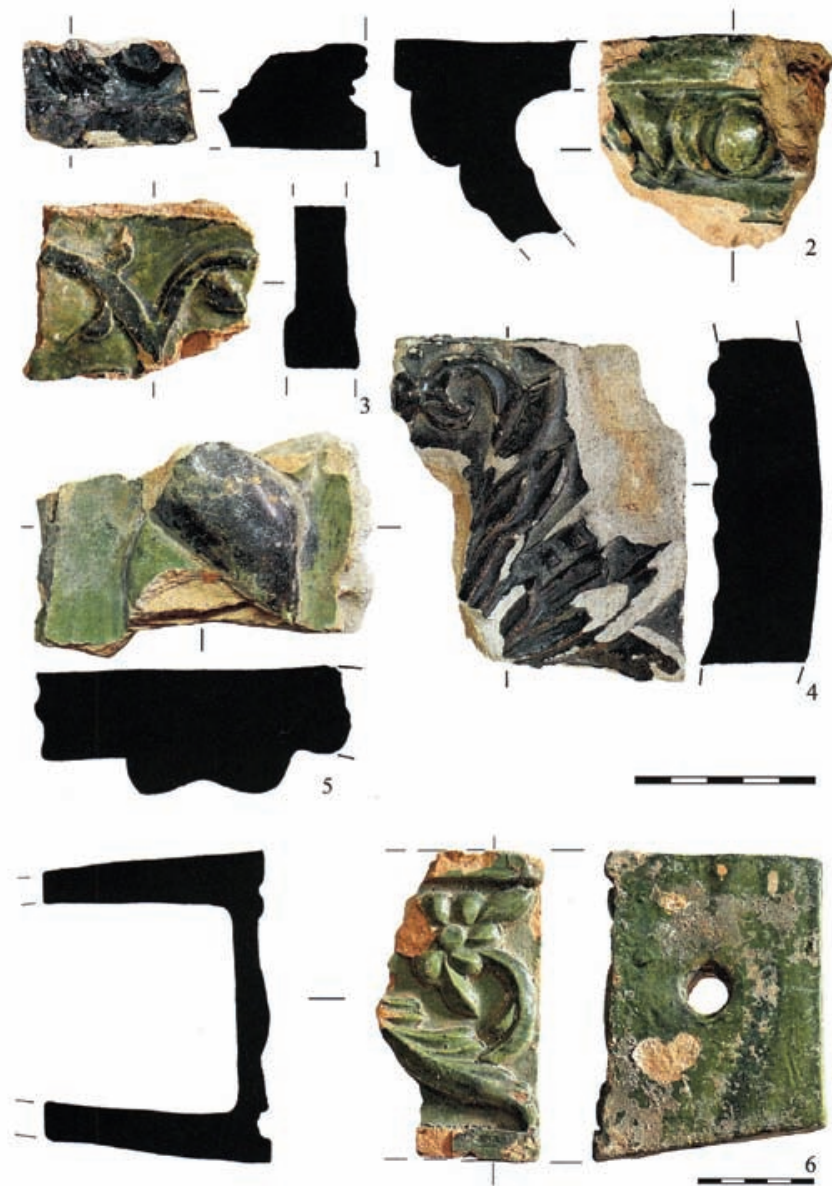

Рис. 6. Фрагменты поливных изразцов, обнаруженные в 2012-2013 годы в центральной части западного крыла тверского Императорского дворца. Середина - вторая половина XVI века (источник: [1, цв. вклейка: рис. 9])

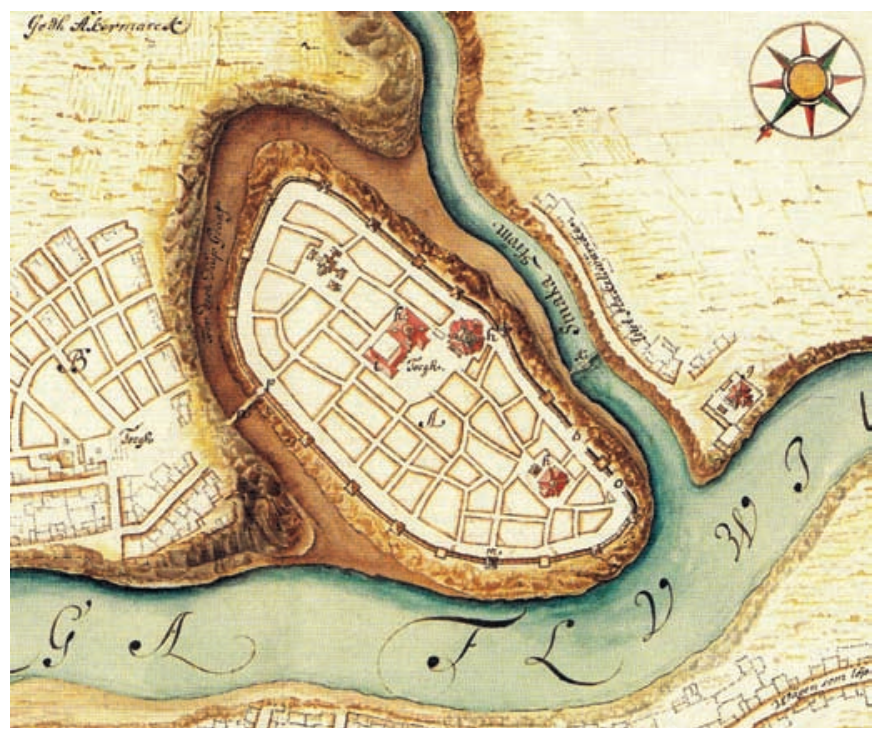

Рис. 7. Тверской кремль на плане, выполненном Э. Пальмквистом. 1674 год (источник: [4, с. 14]) 
Размеры и состав помещений Владычных палат XVII века содержатся в переписи 1701 года. Частями общего здания были: крестовая и столовая палаты, «две кельи архиерейские» каменные и «келья о трёх жильях». Между крестовой и столовой палатами находились сени, из которых на владычный двор вели «переднее и заднее крыльца и всходы и рундуки каменные». Под всеми перечисленными выше помещениями находились жилые подклеты ${ }^{7}$, то есть здание было двухэтажным, таким как его схематически передаёт чертёж 1710-х годов (см. рис. 1).

В 1999 году Владычную палату удалось обнаружить в заложенной по всей длине курдонера (по оси север-юг) траншее. Здесь были зафиксированы фундаментные рвы и, что чрезвычайно важно, - фрагментарно уцелевшее мощение in situ ${ }^{8}$ из уложенных плашмя «в ёлочку» кирпичей, которое со всей очевидностью свидетельствовало о том, что траншея пересекла владычные палаты. Устроенное внутри здания мощение состояло из кирпичей размером $(28,5 \ldots 29) \times 15 \times(7 \ldots 7,5)$ см.

Выводы, сделанные на основе работ 1999 года, получили подтверждение в 2012 году при дополнительных исследованиях в северо-восточной части курдонера. В шурфе и траншее, заложенных недалеко от внутреннего северо-восточного угла дворца, были обнаружены подошвенные элементы фундаментных конструкций, которые формировали угол некогда разобранной средневековой постройки. Фундаменты сохранили здесь лишь подошвенную часть, включающую колотый известняк, валуны и единичные фрагменты обломков кирпичей, залитые известковым раствором. Ниже располагались вбитые в грунт сваи. Ширина фундаментной ленты в обоих случаях была равна одному метру.

Приблизительно в центре курдонера удалось выявить ещё одну опорную конструкцию. В 1999 году она была разорвана ковшом экскаватора, а в 2012-ом устроенный здесь шурф расширил траншею 1999 года (до двух метров), поэтому в юговосточном и юго-западном углах шурфа были обнаружены два фрагмента одного, лежащего по оси восток-запад фундамента, сохранившегося на высоту 70-90 см. Очевидно, что обнаруженная конструкция имеет северную лицевую плоскость, так как вертикальная поверхность блоков с этой стороны кладки неплохо обработана, хотя в забутовке немало грубоколотого известняка, к которому добавлены валуны и кирпичный бой. Сложен фундамент на известково-песчаном растворе, а подстилают его деревянные лежни, уложенные по оси восток-запад на гумусированный грунт. В поперечнике эти субструкции достигали 15 см. Если принять во внимание данные 1999 года, то ширина этой конструкции составляла ориентировочно 80-90 см.

Суммируя сведения о выявленных в северной и центральной частях курдонера опорных элементах, фундаментных рвах, а также кирпичном мощении, есть все основания утверждать, что в данном случае мы имеем дело с Владычным

7 РГАДА. Ф. 1209. 0п. 1. Д. 470. 1685-1686 гг. Л. 91.

8 in situ - в архитектурной археологии так называют непотревоженные остатки обнаруженного во время раскопок здания.

${ }^{9}$ РГАДА. Ф. 248. «Сенат». Кн. 625. Л. 443 об., 445 об. дворцом, отмеченным источниками последней четверти XVII - начала XVIII века. По всей видимости, именно это здание в качестве главных архиерейских палат было создано архиепископом Иоасафом в 60-е - начале 70-х годов XVII века.

В свою очередь, результаты, полученные в процессе многолетних архитектурно-археологических исследований на территории Императорского дворца в Твери, позволили, на наш взгляд, окончательно отказаться от бытовавшей до начала раскопок и продолжающей бытовать версии, предполагающей включение части дворца архиепископа Иоасафа в состав ныне существующего здания. Правда, выведя позднесредневековые элементы из состава ныне существующего здания, подчеркну, что, в процессе реставрационных работ в его структуре действительно были выявлены участки стен, появившиеся до пожара 1763 года. Следовательно, тверской Императорский дворец, возведённый в середине 60-х - 70-е годы XVIII века, создавался на основе Владычного дворца, сооружённого во второй половине 1730 -х годов.

Строительство в Тверском кремле в 30-е годы XVIII века сопровождалось, по всей видимости, разборкой не только надземных частей повреждённых пожаром зданий. Если судить по данным архитектурно-археологических исследований, то практически до подошвы были выбраны и фундаменты Владычного дома. Получается, что заказчики и соответственно исполнители старались максимально полно использовать бывший в употреблении строительный материал. Не исключено, что также поступили с Владимирской башней Тверского кремля 1674 года, которая в конце 30-х годов XVIII века стала «каменоломней» при строительстве новой воеводской канцелярии ${ }^{9}$.

Подводя итог изучению Архиерейского двора в Твери, следует отметить, что, несмотря на индивидуальность его внешнего облика, в основе формирования тверского комплекса лежат общие для целого ряда жилых ансамблей высшего духовенства композиционные приёмы. Сегодня об этой близости можно говорить на примере резиденций, получивших своё завершение в XVII-XVIII веках, но структурная аналогичность могла иметь место и в более раннее время. Допускаю, правда, что главная постройка архиерейского комплекса - Владычный дворец - могла менять своё местоположение. Отчасти эта версия находит подтверждение при анализе результатов архитектурно-археологических исследований, проведённых в 2012-2014 годы на территории утраченного в 1935 году кафедрального Спасо-Преображенского собора конца XVII века [7]. Обнаруженные на его месте остатки белокаменного цоколя довольно значительного по площади деревянного жилого здания (ориентировочно $28 \times 28$ м), созданного, по всей видимости, в конце XIV - начале XV века [8, с. 265], вполне могут быть соотнесены с парадными палатами тверского архиерея, включавшими целый ряд разных по площади помещений.

0 каменных сооружениях Владычного двора в Тверском кремле не сообщают даже источники XVI века, однако, зная, что каменное «палатное» строительство велось в XIV веке новгородским [9, с. 30-31], а в XV веке - суздальским [10, с. 165] и, вероятно, московским [11, с. 88] архиереями, допустимо 
предположить, что и у построек архиепископа Иоасафа были каменные предшественники. Вероятность такого вывода велика ещё и потому, что в районе западного крыла Императорского дворца, где в средневековье находились здания Казны и Казённого приказа (см. рис. 4), были найдены изразцы второй половины XV-XVI веков (см. рис. 5, 6), а в белокаменном фундаменте самого Казённого приказа удалось обнаружить малоформатные кирпичи, которые использовали в конце XVXVI веках. В связи с этими находками допускаю, что постройка, обнаруженная в южной половине западного крыла дворца (её площадь составляла приблизительно $17 \times 15$ м), могла стать первым каменным «палатным» сооружением Архиерейского двора. Вероятно, немногим позже к нему пристроили ещё одно каменное здание, что способствовало формированию достаточно крупного двухчастного (?) комплекса, хотя, конечно же, и деревянные строения входили в этот ансамбль.

К сказанному добавим, что в Твери в XVI веке каменные некультовые сооружения существовали и на территории кремлёвского Княжьего двора ${ }^{10}$, а также в 0троче монастыре, где каменную трапезную могли выстроить ещё во второй половине XV века [5, с. 466-467]. Если же принять во внимание обнаруженные в районе западного крыла Императорского дворца терракотовые изразцы (см. рис. 5), появившиеся в Твери во второй половине XV века [5, с. 444-455], то тогда строительство первого каменного здания Владычной резиденции можно отнести ко второй половине XV - началу XVI века. Затем, судя по найденным здесь же изразцам «старицкого» типа (см. рис. 6), в середине XVI столетия эта палата могла быть обновлена, что, возможно, сопровождалось устройством на её фасаде (или фасадах) керамической иконы (или икон) по типу тех, что украшали Борисоглебский собор в Старице, выстроенный в 1558-1561 годы.

Замечу, что такое внимание к декоративной составляющей этого сооружения в середине XVI века может быть объяснено тем фактом, что именно в это время или несколько ранее к рассматриваемому нами зданию перешла функция основной дворцовой постройки архиерейского комплекса, которой до этого мог быть наделён корпус, остатки которого были обнаружены на месте Спасо-Преображенского собора конца XVII века. Это деревянное сооружение, очевидно, погибло в июле 1537 года, когда в результате пожара «весь град выгоре» ${ }^{11}$. Неизвестно, было ли оно потом восстановлено, но, вполне вероятно, что после пожара расположенное к северу от него каменное здание второй половины XV - начала XVI века стало основной постройкой архиерейского комплекса.
Если летом 1537 года эта палата осталась единственным уцелевшим во время пожара жилым зданием Архиерейской резиденции, то есть основание полагать, что отремонтировали его уже в 1537 году. В качестве аргумента для такого вывода важен тот факт, что в районе этой палаты были обнаружены не только изразцы «старицкого типа», но и ещё несколько фрагментов поливных изразцов ${ }^{12}$, которые, хотя и отличаются от «старицких», тем не менее и стилистически, и технологически близки им и, следовательно, предварительно могут быть датированы XVI столетием. И не обязательно серединой - второй половиной XVI века, поскольку во Пскове поливные изразцы появляются ещё в конце XV века, и ими продолжают украшать псковские храмы первой половины - середины XVI века [12; 13, с. 30-31]. Следовательно, и второй пока ещё не имеющий аналогов в средневековом искусстве Древней Руси тип тверских изразцов XVI веа (?) может быть, к примеру, соотнесён с концом 1530-хили с 1540-ми годами.

Допускаю также, что строительство во второй половине XV начале XVI века каменной палаты на месте будущего Казённого приказа могло быть обусловлено тем, что рядом находился каменный храм, созданный, по всей видимости, ещё в начале XV века [8, с. 380-394]. Эта церковь после возведения во второй половине XV - начале XVI века каменного жилого здания по сути дела стала домовым храмом тверского архиерея.

Позже, во второй половине XVII века, когда архиепископ Иоасаф восстанавливал Владычный двор после пожара 1661 года, за каменными постройками XV-XVI веков были, вероятно, оставлены исключительно административные функции (Казённый приказ, казначейская келья и др.), а новое дворцовое здание владыка выстроил к востоку от более ранних каменных построек ансамбля Архиерейского двора, сформировав, вероятно, из основных сооружений Владычной резиденции Г-образную в плане объёмно-пространственную композицию. Такой вывод находит подтверждение при оценке плана 1674 года (см. рис. 7), поскольку если «пристыковать» ошибочно объединённые Э. Пальмквистом со Спасо-Преображенским собором архиерейские корпуса с церковью Происхождения честных древ, то тогда сложившуюся композицию с полным правом можно соотнести с реконструкцией архиерейского комплекса (см. рис. 4), выполненной на основании результатов, полученных во время архитектурно-археологических исследований на территории бывшего Владычного двора.

Вероятно, при Иоасафе или в последующие десятилетия XVII века в состав Архиерейской резиденции вошёл ещё ряд каменных зданий, а также ограда, охватившая со всех сторон владычную резиденцию ${ }^{13}$.

\footnotetext{
${ }^{10}$ Фиксируя запустение Княжьего двора в Тверском кремле после Смуты, составитель писцовой книги 1626 года отмечает, что напротив «завалившегося» Борисоглебского храма «стоит палата каменная оболилась» (Выпись из тверских Писцовых книг Потапа Нарбекова и подъячего Богдана Фадеева. 1626 год. - Тверь, 1901. - С. 12). Этот факт, на наш взгляд, с очевидностью свидетельствует о постройке этого здания не позже конца XVI века.

${ }^{11}$ Полное собрание русских летописей. Т. 6. - СПб., 1853. - С. 303.

${ }^{12}$ Лапшин В.А. Опись индивидуальных находок: № 27 // Археологические исследования (раскопки, надзор) в Тверском Кремле на участках подводки подземных коммуникаций к зданию бывш. Путевого дворца через Волжский проезд в 1998 г. (раскоп Кремль-15, ул. Советская, д. 3) : 0тчёт. Ч. 1. - СПб.Тверь, 1999. Опись индивидуальных находок: № 27 // Архив ТГОМ.

${ }^{13}$ В.А. Лапшин ошибочно, на наш взгляд, полагает, что та часть ограды, где «находились Житенный двор, огороды и конюшни ... была сооружена после пожара 1736 г., когда архиепископ Митрофан в 1739 г. предпринял перестройку усадьбы» [14, с. 51].
} 
В 1736 году Владычный дом был сильно повреждён пожаром, и несколькими годами позже, после разборки корпуса XVII века, новый дворец возвели к северу от позднесредневековой постройки. Допускаю, что в данном случае могли руководствоваться не только отсутствием желания возобновлять, возможно, серьёзно пострадавшее в пожар здание, но и стремлением соответствовать новым тенденциям, нацеленным на отказ от использования древнерусских образцов и замену их стилистически иными архитектурными формами.

\section{Лuтература}

1. Хохлов, А.Н. Архитектурная керамика XV - первой половины XVIII вв. из раскопок владычного двора в Твери (по материалам археологических исследований 2012-2013 гг. на территории тверского Императорского дворца) / А.Н. Хохлов , В.Р. Мелькова // Тверь, тверская земля и сопредельные территории в эпоху средневековья : Сборник статей. Вып. 10. - Тверь, 2017. - 392 с. - С. 206-224.

2. Реставрация памятников архитектуры : Учебное пособие для вузов / С.С. Подъяпольский, Г.Б. Бессонов, Л.А. Беляев, Т.М. Постникова. - М. : Стройиздат, 1988. - 264 С. ISBN 5-274-00009-6

3. Чередеев, К К. Биографии тверских иерархов от начала существования архиерейской кафедры в г. Твери и доныне / К.К. Чередеев. -Тверь : Типография Губернского Правления, 1859. - 299, VI c.

4. Заметки о России, сделанные Эриком Пальмквистом в 1674 году. - М. : Ломоносовъ, 2012. - 340 с

5. Салимов, А.М. Средневековое зодчество Твери и прилежащих земель : монография : в 2 томах. Том. 1/ А.М. Салимов. - Тверь : Срочно!, 2015.

6. Салимов, А.М. Архиерейский двор в Тверском кремле на рубеже XVII-XVIII столетий: местоположение, границы, характер застройки / А.М. Салимов // Архитектурное наследство. - 2008. - Вып. 49. - С. 119-122.

7. Беляев, Л.А. Спасо-Преображенский собор в Тверском кремле: итоги раскопок 2012-2014 гг. / Л.А. Беляев, И.А. Сафарова, А.Н. Хохлов // Российская археология. - 2018. № 2. - С. 148-161.

8. Салимов, А.М. Тверской Спасо-Преображенский собор. XIII - начало XXI века / А.М. Салимов. - Тверь : Торг. компания «АНТЭК» : Твер. ред.-изд. фирма «РИФ», 2019. - 376 с.

9. Гордиенко, Э.А. Владычная палата Новгородского кремля / Э.А. Гордиенко. - Л. : Лениздат, 1991. - 108 с.

10. Воронин, Н.Н. Владимир, Боголюбово, Суздаль, ЮрьевПольской / Н.Н, Воронин. - М. : Искусство, 1983. - 295 с.

11. Тиц А.А. Новые данные о Патриаршем дворе в Кремле / А.А. Тиц // В кн. «Архитектурное наследство». Т. 14. - М., 1962. - С. 75-88.

12. Плешанова, И.И. Псковские архитектурные керамические пояса / И.И. Плешанова // Советская археология. - 1963. - № 2. - С. 211-226.
13. Седов, В.В. Псковская архитектура XVI века : монография / В.В. Седов. - М. : Общество историков архитектуры, 1996. -304 C.

14. Лапшин, B.A. Тверь в XIII - XV вв. (по материалам раскопок 1993-1997 гг. - СПб : Факультет филологии и искусств СПбГУ, 2009. - 540 с. ISBN 978-5-8465-0917-7

\section{References}

1. Khokhlov A.N., Mel'kova V.R. Arkhitekturnaya keramika XV - pervoi poloviny XVIII vv. iz raskopok vladychnogo dvora v Tveri (po materialam arkheologicheskikh issledovanii 2012-2013 gg. na territorii tverskogo Imperatorskogo dvortsa) [Architectural ceramics of the 15th - first half of the 18th centuries from the excavations of the Vladyka's court in Tver (based on the materials of archaeological research in 2012-2013 on the territory of the Tver Imperial Palace)]. In: Tver', tverskaya zemlya i sopredel'nye territorii v epokhu srednevekov'ya [Tver, Tver land and adjacent territories in the Middle Ages], Is. 10. Tver', 2017, 392 p., pp. 206-224.

2. Pod"yapol'skii S.S., Bessonov G.B., Belyaev L.A., Postnikova T.M. Restavratsiya pamyatnikov arkhitektury [Restoration of architectural monuments]. Moscow, Stroiizdat Publ., 1988, 264 p. ISBN 5-274-00009-6

3. Cheredeev, K. K. Biografii tverskikh ierarkhov ot nachala sushchestvovaniya arkhiereiskoi kafedry $\vee \mathrm{g}$. Tveri i donyne [Biographies of the Tver hierarchs from the beginning of the existence of the bishop's chair in the city of Tver and to this day]. Tver', Typography of the Provincial Board, 1859, 299, VI p.

4. Zametki o Rossii, sdelannye Erikom Pal'mkvistom v 1674 godu [Notes on Russia by Eric Palmquist in 1674]. Moscow, Lomonosov"" Publ., 2012, 340 p.

5. Salimov A.M. Srednevekovoe zodchestvo Tveri i prilezhashchikh zemel' [Medieval architecture of Tver and adjacentlands], in 2 volumes. Vol. 1. Tver', "Srochno!" Publ., 2015.

6. Salimov A.M. Arkhiereiskii dvor v Tverskom kremle na rubezhe XVII-XVIII stoletii: mestopolozhenie, granitsy, kharakter zastroiki [Bishop's court in the Tver Kremlin at the turn of the XVII-XVIII centuries:location, boundaries, nature of the building]. In: Arkhitekturnoe nasledstvo [Architectural heritage], 2008, Is. 49, pp. 119-122.

7. Belyaev L.A., Safarova I.A., Khokhlov A.N. SpasoPreobrazhenskii sobor $v$ Tverskom kremle: itogi raskopok 2012-2014 gg. [Transfiguration Cathedral in the Tver Kremlin: the results of excavations in 2012-2014]. In: Rossiiskaya arkheologiya [Russian archeology], 2018, no. 2, pp. 148-161.

8. Salimov A.M. Tverskoi Spaso-Preobrazhenskii sobor. XIII - nachalo XXI veka [Tver Spaso-Preobrazhensky Cathedral. XIII - early XXI century]. Tver', Trade company "ANTEK", Tver. red.-izd. firma "RIF", 2019, 376 p.

9. Gordienko E.A. Vladychnaya palata Novgorodskogo kremlya [The Vladyka Chamber of the Novgorod Kremlin]. Leningrad, Lenizdat Publ., 1991, 108 p. 
10. Voronin N.N. Vladimir, Bogolyubovo, Suzdal', Yur'evPol'skoi [Vladimir, Bogolyubovo, Suzdal, Yuryev-Polskoy]. Moscow, Iskusstvo Publ., 1983, 295 p.

11. Tits A.A. Novye dannye o Patriarshem dvore v Kremle [New data on the Patriarch's court in the Kremlin]. In: Arkhitekturnoe nasledstvo [Architectural heritage], Vol. 14. Moscow, 1962, pp. 75-88.

12. Pleshanova I.I. Pskovskie arkhitekturnye keramicheskie poyasa [Pskov architectural ceramic belts]. In: Sovetskaya arkheologiya [Soviet archeology], 1963, no. 2, pp. 211-226.
13. Sedov V.V. Pskovskaya arkhitektura XVI veka [Pskov architecture of the XVI century]. Moscow, Society of Architectural Historians Publ., 1996, 304 p.

14. Lapshin V.A. Tver' v XIII-XV vv. (po materialam raskopok 1993-1997 gg.) [Tver in the XIII-XV centuries (based on materials from excavations in 1993-1997]. Saint Petersburg, St. Petersburg, Faculty of Philology and Arts, St. Petersburg State University Publ., 2009, 540 p. ISBN 978-5-8465-0917-7

Салимов Алексей Маратович (Тверь). Доктор искусствоведения, член-корреспондент РААСН. Главный научный сотрудник Научно-исследовательского института теории и истории архитектуры и градостроительства (филиал ФГБУ «ЦНИИП Минстроя России») (111024, Москва, ул. Душинская, 9. НИИТИАГ). Эл.почта: sampochta@mail.ru.

Salimov Aleksey M. (Tver). Doctor of Arts, Corresponding Member of RAACS. Chief Researcher at the Research Institute of Theory and History of Architecture and Urban Planning (9 Dushinskaya st, Moscow, 111024. NIITIAG), branch of the Central Institute for Research and Design of the Ministry of Construction and Housing and Communal Services of the Russian Federation (TsNIIP Minstroy of Russia). E-mail: sampochta@mail.ru. 